UDK 811.111'282.2(73) '342

DOI https://doi.org/10.24919/2308-4863/45-1-18

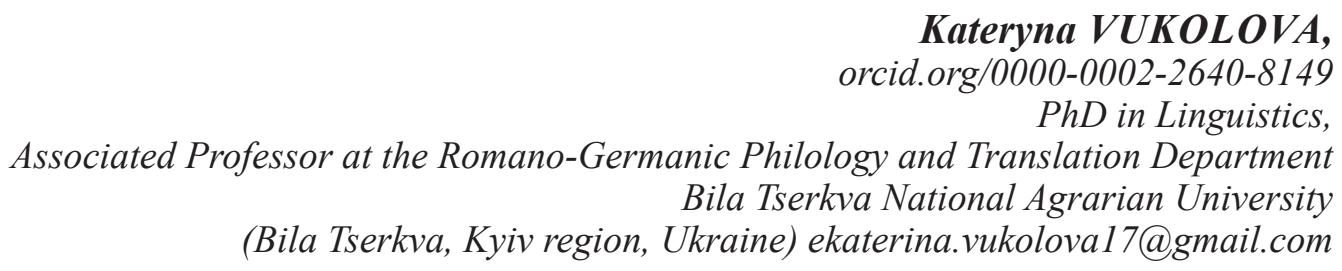

Tatiana SMOLIANA, orcid.org/0000-0001-6628-2707

PhD in Linguistics, Associated Professor at the German Philology and Translation Department V. N. Karazin Kharkiv National University

(Kharkiv,Ukraine) germphil@karazin.ua

\title{
LINGUISTIC MOSAIC OF MIDLAND DIALECT CONTINUUM (MDC) IN FRAMES OF AMERICAN ENGLISH (PHONETIC ASPECT)
}

The linguistic characteristics of Midland Dialect Continuum mainly phonetic peculiarities have been given in this paper. From a linguistic point of view, the Midland Dialect Continuum is the "third dialect" of the northern type of pronunciation of American English. Midland dialect region comprises the cities of Nebraska, Iowa, Illinois, Indiana, Ohio, Kansas and Missouri such as Omaha, Ottumwa, Champaign, Indianapolis, Columbus, Wichita, Kansas City, Columbia, St Louis respectively. Compared to American English, the speech inherent in the Midland Dialect Continuum has features at three language levels: phonetic, lexical and grammatical. At this very article the authors have considered the phonetic features of the Midland Dialect Continuum. Among the phonetic features have been found the following: merging the vowels of the back row of the lower elevation / $\mathrm{s}$ / / and / $\mathrm{p} /$; use of schwa [a] (middle row of middle rise in the stressed position); fronting / ou /; fronting / u: /; Fronting of / av /; epenthetic / $/$ /; short-a phoneme, /ae/; fronting of / $/$; lowering of /eI/. All the investigated issues within this region are exceptional characteristics which add a unique color and are a tool for self-identification of the inhabitants of the studied area. The grammatical and lexical peculiarities are being the perspectives of the further research which relevance is determined, first, by a new perspective on the analysis of speech variability depending on the influence of selected extra lingual factors: gender, ethnicity, social status and age, which, of course, corresponds to the current state of linguistics and growing interest in the social factors influencing on the speech in different areas, as well as the application of an eco-linguistic approach to the analysis of sociolinguistic differentiation of the Midland Dialect Continuum. Second, the study is quite interesting in light of the importance of the sociocultural role of the dialects of the Midland Dialect Continuum in the holistic linguistic pattern of the United States of America.

Key words: Midland Dialect Continuum, American English, phonetic peculiarities, monophtongization, vowels.

Катерина ВУКОЛОВА, orcid.org/0000-0002-2640-8149 кандидат філологічних наук, доиент кафедри романо-германської філології та перекладу Білоиерківського начіонального аграрного університету (Біла Церква, Київська область, Україна) ekaterina.vukolova17@gmail.com

Тетяна СМОЛЯНА, orcid.org/0000-0001-6628-2707 кандидат філолологічних наук,

доцент кафедри німецької філології та перекладу Харківського наиіонального університету імені В. І. Каразіна

(Харків, Украӥна) germphil@karazin.ua

\section{ЛІНГВІСТИЧНА МОЗАЇКА МІДЛЕНДСЬКОГО ДІАЛЕКТНОГО КОНТИНУУМУ В РАМКАХ АМЕРИКАНСЬКОГО ВАРІАНТУ СУЧАСНОЇ АНГЛІЙСЬКОЇ МОВИ (ФОНЕТИЧНИЙ АСПЕКТ)}

У даній статті було авторками було наведено мовні характеристики Мідлендського діалектного континууму (МДК), зокрема, фонетичні. 3 лінгвістичної точки зору, МДК є «третім діалектом» північного типу вимови 
американського варіанту сучасної англійської мови. Територія даного діалектного регіону (МДК) включає такі штати як Небраска, Айова, Іллінойс, Індіана, Огайо, Канзас і Міссурі, та міста Омаха, Оттумва, Шампань, Індіанаполіс, Вічіта, Канзас-Сіті, Колумбія, Сент-Луіс відповідно. Порівняно з американським варіантом сучасної англійською мовою, риси, притаманні МДК відслідковуються на всії трьох мовних рівнях: фонетичному, лексичному та граматичному. У иій статті автори розглянули фонетичні особливості МДК. Серед фонетичних ознак були виявлені наступні: злиття голосних заднього ряду нижнього піднесення /s: /ma /p /; використання schwa [ə] (середній ряд середнього підйому в напруженому положенні); фронтування / об /; фронтування / и: /;

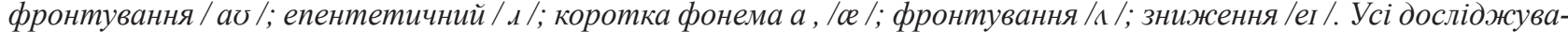
ні проблеми в иььому регіоні є винятковими характеристиками, які додають унікальний колорит іє інструментом для самоідентифікаиії мешканиів досліджуваної території. Вивчення граматичних та лексичних особливостей $\epsilon$ перспективою подальших досліджень, актуальність яких визначається, по-перше, новим поглядом на аналіз мінливості мовлення залежно від впливу вибраних позамовних чинників: статі, етнічної належності, соціального статусу та віку, які, звичайно, відповідають поточному стану мовознавства та зростаючому інтересу до соиіальних факторів, щчо впливають на мовлення у різних сферах, а також застосуванню еколінгвістичного підходу до аналізу соиіолінгвістичної диференціації МДК. По-друге, дослідження є досить изікавим у світлі важливості соціокультурної ролі діалектів МДК у иілісній лінгвістичній моделі Сполучених Штатів Америки.

Ключові слова: Мідлендський діалектний континуум, американський варіант сучасної англійської мови, фонетичні властивості, монофтонгізачія, голосні.

Problem statement. The development of modern linguistics is characterized by the replacement of paradigms of language and speech study, where much attention is paid to the study of its dynamic characteristics, which is carried out in the framework of synergetics and sociolinguistics. Whereas the language is a dynamic phenomenon, the question of its variability is always extremely relevant. Linguistic science can obtain a basis for more accurate prediction of the development of English as a macro-language system consisting of appropriate national and territorial subsystems in the context of establishing deviations from the codified standards and patterns of variation of language units in the speech of native speakers.

Research analysis. The English language, as a result of the development and interaction of its national and territorial subsystems has been studied in many ways, in particular in terms of systematization of their assimilation and dichotomous features (Ya. Zatsny, M. Kolisnyk, J. Chambers, D. Jones, R. Kingdon, I. Trevian, P. Trudgill, etc.). The specificity of sociocultural variation of speech is presented in the works of I. Shevchenko, V. Pasynok, A. Fill, E. Haugenn, etc.; sociolinguistic variability of speech of the Midland Dialect Continuum (MDC) became the object of research of B. Johnstone, U. Labov and others.

The study of the peculiarities of any language within limits determines its consideration not as a homogeneous, monolithic formation, but as a rather complex and multifaceted phenomenon.

The role of language in life of any society and individual communities, the influence of social and stratification factors on linguistic changes in the society, the totality of linguistic and political relations, motives of behavior and activities of the subjects of such relations are the spectrum of language activity of the state and society, individual, family, team, ethnic community, etc.
This article is devoted to one of the topical issues of modern linguistics - the linguistic pattern of usages formed in an appropriate area. The purpose of the article is to consider the phonetic peculiarities of the MDC linguistic mosaic in the frames of American English.

\section{Characteristics of current language situation of United States of America}

In order to conduct a local study of speech within Midland Dialect Continuum (MDC), it is necessary to demonstrate the general characteristics of the language situation in the United States. This information will help to understand the diversity of the country's population, as well as help to trace the influence of different languages on American English, and in particular the MDC (Lakoff, 1973: 45-79).

The current language situation in the United States of America opens up enormous opportunities for researchers to identify the social factors and processes that shape at the latest stage of development the main directions of change in language. Among the most important reasons influencing the linguistic portrait as a whole are the following: many nationalities of a country with a complex texture of linguistic and interethnic relations; continuous migration processes even in conditions of lockdown caused by the COVID-19 virus; population mobility related to employment and job search; the influence of the media. These ones and many other factors have led to significant changes in the language situation.

The United States is one of the few countries that have existed for more than 200 years without an official state language defined at the federal level. However, the English language is de facto the main in such areas of activity as: civil service, community service, office work, education, etc.

The US Constitution does not declare that English as the state language (Zimmerman, 1975: 105-129), but some state governments have recently enacted laws that make English the official one. The reason for 
this is the constant increase in threats from language minority groups.

It should be noted that English has received the status of an official language so far in 37 states (States with Official English Laws). This law was first passed in Nebraska (1923) (URL: https://en.wikipedia.org/ wiki/English-only_movement\#cite_note-44). West Virginia became the last state to pass an official English law to date (2016) (URL: https://en.wikipedia. org/wiki/English-only_movement\#cite_noteCrawford50-33).

In 2013, another attempt was made by the US government - the law of March 6, 2013 HR $997 \mathrm{IH}$ "The English Language Unity Act of 2013" - to recognize English as the official one, but at the 113th session of Congress the document was rejected by the US Congressional Committee for further introduction edits (URL: https://www. congress.gov/bill/113th-congress/house-bill/997/ text\#H9249221781A3424F85619C1C136AD239)/

For a number of reasons, the United States has a rather complex and dynamic ethnic situation. However, the main one, in our opinion, is the high level of migration. Going further back 1908, I. Zangwill in a self-titled play about the life of Jewish immigrants in the United States called this country as a "melting pot" ("melting pot"), which indicated a large number of immigrants of various origins (Wisnosky, 2003:103). According to statistics, Statista is a leading provider of market and consumer data (URL: https://www.statista.com/statistics/183483/rankingof-languages-spoken-at-home-in-the-us-in-2008/), only $81.19 \%$ of US residents speak only English, while $18.81 \%$ use it as a native language in everyday communication [see Table 1]. The largest group of non-English speakers consists of representatives who speak Indo-European languages, namely: Spanish, French, German - 13.36\%, where 12.73\% are Hispanic residents. Spanish is used by speakers only at home. The second largest group belongs to the Sino-Tibetan languages $-1.1 \%$. The population using other languages is $4.4 \%$ (URL: https:// Www.americanimmigrationcouncil.org/research/ immigrants-in-the-united-states? _cf_chl_jschl_tk $=$ pmd_8c6407cc10ab08643d20d2aaf01740836ab27 46b-1626768688-0-gqNtZGzNAjijcnBszQjO).

According to the Bureau of the Census (Bureau of the Census is the leading source of statistical information about the nation's people. This population statistics come from decennial censuses, which count the entire US population every ten years, along with several other surveys), the US population is also extremely diverse in race and ethnicity: $76.3 \%$ of Americans are white (non-Hispanic); 13.4\% consider themselves as African Americans; $2.8 \%$ are two or more races; $5.9 \%$ refer to the Asian race; Native Hawaiian and Other Pacific Islanders - 0.2\%; American Indian and Alaska Natives (Eskimos, Aleutians) make up about $1.3 \%$ of the population, $0.1 \%$ of the population refer to other races [see Table. 1].

Table 1

Languages spoken (at home) other than English in the United States by number of speakers in 2019

\begin{tabular}{|c|c|c|}
\hline $\begin{array}{c}\text { Languages spoken } \\
\text { (at home) other than } \\
\text { English }\end{array}$ & $\begin{array}{c}\text { Number of } \\
\text { speakers }\end{array}$ & Percentage \\
\hline Spanish & $41,757,391$ & $12.73 \%$ \\
\hline French (incl. Cajun) & $1,171,775$ & $0.36 \%$ \\
\hline German & 895,309 & $0.27 \%$ \\
\hline Russian & 941,454 & $0.28 \%$ \\
\hline $\begin{array}{c}\text { Chinese (incl. } \\
\text { Mandarin, Cantonese) }\end{array}$ & $3,494,544$ & $1.1 \%$ \\
\hline Korean & $1,075,247$ & $0.32 \%$ \\
\hline Vietnamese & $1,570,526$ & $0.5 \%$ \\
\hline Tagalog & $1,763,585$ & $0.54 \%$ \\
\hline Haitian & 924,817 & $0.28 \%$ \\
\hline Other languages & $7,877,749$ & $2,4 \%$ \\
\hline
\end{tabular}

According to the U.S. Census Bureau, one in seven U.S. residents is an immigrant, which is about $13.6 \%$ of Americans born outside the United States. According to the American Immigration Council, almost all nationalities of the world are represented in the United States. The top countries of origin for immigrants were Mexico (25\% of immigrants), India (6\%), China (5\%), the Philippines (4\%), and El Salvador (3\%) (URL: https://www.census.gov/ quickfacts/fact/table/US/PST045219). Based on the above statistics, it can be argued that the US population is a complex combination of people from Europe, Asia and Africa.

Table 2

Ethnic pattern of USA population on April, 1, 2020

- White
- African American
- Asian
Two or more races
= Native Hawaiian
and Other Pacific
Islanders
- American Indian
and Alaska Natives


There are almost 44 million people in the English-speaking population - the African American population - who use the so-called "African American Vernacular English" (AAVE). This dialect was developed during the time of slavery in the southern United States. However, during the "before and after" World War II there was a mass migration of the African American population to the North (New York, Chicago, Detroit, etc.). Many sociolinguists, in particular, W. Labov, who studied the pronunciation features of African Americans in northern cities, believe that all these features are driven by the social factors.

An objective documented description of the regional properties of American English is presented in DARE - Dictionary of American Regional English edited by F. Cassidy. In the preface to this dictionary, J. Hartmann points to the need to select certain pronunciation features that can be correlated with the corresponding features of the compared dialect as the only way to prove the identity of the language of any regional or social group of individuals.

Finding such a set of defining parameters of the phonological regional language was one of the tasks of the nationwide Telsur project - a study of linguistic changes taking place in North America today. The project is supported by the National Science Foundation and the National Endowment for the Humanities. The result of this project was the creation of the Phonological Atlas of North American English (1997). As a result, the territory of the United States was divided into several language areas: North, North Midland, South Midland, South and West. The obtained data allowed the authors to confirm the existence of three main dialect areas: North, Midland and South (data obtained by American scientists $\mathrm{H}$. Kurath and JR. McDavid during the preparation of the Linguistic Atlas of the United States). At the same time, on the basis of systemic changes of vowels, in particular the northern shift of vowels, the borders of dialects and the division of the North into the Central, Inner and North-Eastern territories were specified; Midland - to the North and South, bordering the South and West according to Yale Grammatical Diversity Project (URL: https://ygdp.yale.edu/phenomena/ needs-washed).

An important feature of American society's speech is that none of the regional types of pronunciation have the status of a pronunciation standard. According to scholars who study the language within the influence of social factors (so-called external factors), this situation is justified by the influence of the media, where the phonetic training of speakers focuses on Northern and Western types of pronunciation, including Midland pronunciation. Thus, it has been noted that the Southern pronunciation is rejected as unacceptable, and therefore socially marked.

Another important reason that affects the change of speech sounds is the high mobility of the population. Despite the circumstances surrounding the spread of COVID-19 and the introduction of quarantine throughout the country, an increasing number of people are currently traveling great distances for a variety of reasons, respectively, coming into contact with each other. In this regard, J. Chambers notes that when people talk with colleagues, neighbors, travelers from distant places, they not only communicate with others, but also involuntarily adopt some of the pronunciation features of our interlocutors, just as they adopt ours. This source of variability is more significant, because the process of communication is infinite (Chambers, 1998: 123-132).

Thus, it should be stated that the population of the United States is multinational: there are people from Europe, Asia and Africa, which, of course, complicates the rather dynamic ethnic situation. The reason for such a difficult language situation, in our opinion, is the increased mobility of the population within the country, the high level of immigration from abroad, as well as the widespread use of the media. Given that the status of the English language is not enshrined in the US Constitution, there is a serious threat from the country's foreign-speaking population. In this regard, the US government develops and implements various programs aimed at supporting the English language, as well as enacts local laws under which English becomes an official language.

\section{Evolvement of Midland Dialect Continuum and its place in linguistic pattern of United States of America}

From a linguistic point of view, the MDC is the "third dialect" of the northern type of pronunciation of American English. At present, the clear boundaries of the continuum have not been defined, as it has changed its distribution several times and has sometimes spread.

According to Labov et al.'s (2006) ANAE, the strict Midland dialect region comprises the cities of Nebraska, Iowa, Illinois, Indiana, Ohio, Kansas and Missouri such as Omaha, Ottumwa, Champaign, Indianapolis, Columbus, Wichita, Kansas City, Columbia, St Louis respectively. In the past, linguists considered the Midland dialect to cover an even larger area, extending eastward through Pennsylvania to the Atlantic Ocean. In accordance to Kurath (1949) the territory of MDC included also such areas as Pennsylvania, Northern West Virginia, Southern West Virginia, Delaware Alley (Philadelphia Area), Susquehanna Valley, the Upper Potomac and Shenandoah Valleys, the Upper Ohio Valley 
(Pittsburgh Area), Northern West South Carolina (Kurath, 1949: 261). In fact H. Kurath distinguished eighteen speech areas, which he grouped into three main groups: Northern, Midland, and Southern, which gave a broader overview over the dialect continuum. A decade later, Kurath split this into two discrete subdivisions: the "North Midland" beginning north of the Ohio River valley area and extending westward into central Indiana, central Illinois, central Ohio, Iowa, and northern Missouri, as well as parts of Nebraska and northern Kansas; and the "South Midland", which extends south of the Ohio River and expands westward to include Kentucky, southern Indiana, southern Illinois, southern Ohio, southern Missouri, Arkansas, southern Kansas, and Oklahoma, west of the Mississippi River (Kurath, 1961: 57).

Speech operating in this area is one of the main and most important in the MDC. Compared to American English, the speech inherent in the MDC has features at three language levels: phonetic, lexical and grammatical.

\section{Characteristics of phonetic peculiarities}

The most characteristic differences of the dialects of the MDC are the following phonetic processes:

- merging the vowels of the back row of the lower elevation /o: / and /p/:

caught is pronounced / $\mathrm{k} /: \mathrm{t} / \sim[\mathrm{kpt}]$; dawn is pronounced / don / [dpn].

Speakers who use the sound / $\mathrm{p} /$ instead of [o:] put their lips together.

While the fusion of these low vowels is more common in the United States, the phoneme that results from this fusion is usually not rounded [p].
In southwestern Pennsylvania, speakers pronounce less $[0 \sim \mathrm{p}]$. Pronunciation of the sound $[\mathrm{p}]$ is also common in Canada and northern New England (Lakoff, 1973: 45-47).

- use of schwa [ə] (middle row of middle rise in the stressed position):

Suppose [sə' pouz] = suppose / sə' pəuz /

- fronting / ow /:

go is pronounced as / g3v / [gov]

The diphthong / ov / is pronounced in front of the mouth.

The diphthong / ov / is common in the South, the Midlands, and Pittsburgh itself, but is less common in Columbus and Wichita.

\section{- fronting / u: /}

The vowel / u: / is pronounced further to the front of the mouth and is often diphthongized.

The / u: / front can be found in most of the country, including the South and the West [12, p. 261].

- Fronting of / av /:

house is pronounced as [ha:s]; out is pronounced as [a:t]; found is pronounced as [fa:nd]; downtown is pronounced as [da:ntha:n].

The diphthong / av / becomes a monophthong [a: ] before the nasal sounds (downtown), deaf (fowl, hour) and vowel (house, out, cloudy). Monophthongization does not occur in the final position (how, now), where diphthongs / av / can occur. The sound [a:] is often spelled as [ah]. A colon after [a:] means that the sound is extended. (Eberhardt, 2008: 284-311).

This sound can only be found in southwestern Pennsylvania, and it can still be found in Cockney slang and South African English.

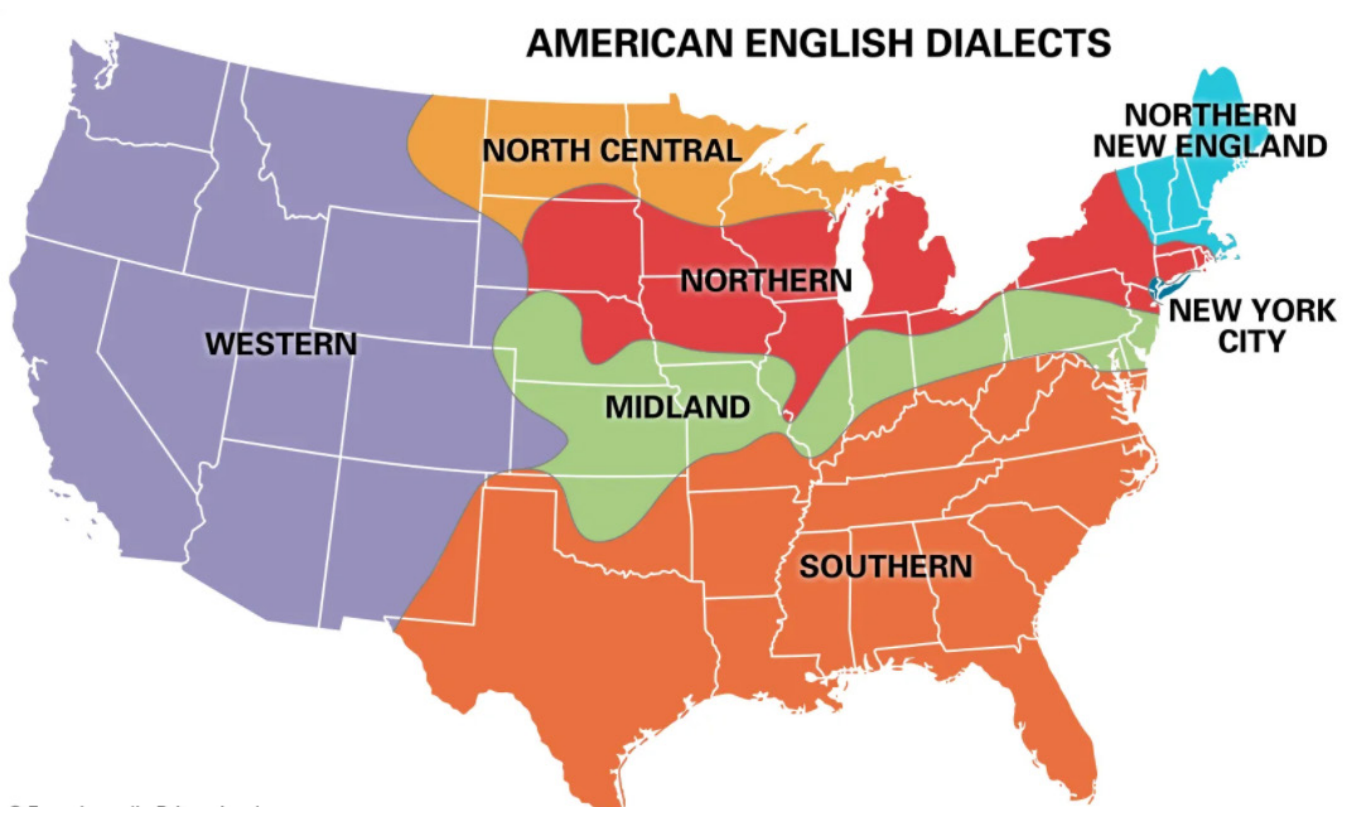

Fig. 1. American English Dialects. Encyclopedia Britannica, Inc. 
The source of this phenomenon may be the contact with the Slavic peoples during the twentieth century (Eckert, 2003: 366).

- epenthetic / I /:

wash is pronounced as ['woxf] or ['wD.If].

Occurs after vowels in words such as water, pronounced as ['wouto 'wDito] (Eberhardt, 2008:284-311).

This sound is common in Southwest Pennsylvania.

- The short- $a$ phoneme, /ar/:

the most commonly follows a General American ("continuous" and pre-nasal) distribution: $/ æ /$ is raised and tensed toward [eə] before nasal consonants (such as fan) but remains low [æ] in other contexts (such as fact). An increasing number of speakers from central Ohio realize the TRAP vowel /æ/ as open front [a] (Thomas, 2004: 300-324).

\section{- Fronting of $/ \mathbf{N} /$ :}

among younger speakers, $/ \Lambda /$ (as in bug, strut, what, etc.) is shifting strongly to the front: [3] (Labov, 2006:266).

\section{- Lowering of /er/:}

the diphthong /eI/ (as inface, reign, day, etc.) often has a lower nucleus than the Northern accents just above Midland region, so that the Midland diphthong approaches [EI 3I] (Labov, 2006: 9).

Phonologically, the South Midland remains slightly different from the North Midland (and more like the American South) in certain respects: its greater likelihood of a fronted /ov/, a pin-pen merger, and a "glideless" /aI/ vowel reminiscent of the Southern U.S. accent, though/aI/deletion in the SouthMidlandonly tends to appear before sonorant consonants: $/ \mathrm{m} /, \mathrm{n} /, / 1 /, / \mathrm{r} /$. For example, fire may be pronounced something like fahr or even far (Labov, 2006: 268).

Conclusions. The importance and significance of the direct study of the peculiarities of the functioning of the language units of the MDC (USA) is due to the fact that the gradual implementation of its results and the results of similar scientific research will solve such issues of international political, cultural and professional communication enrichment of American English based on replacing linguistic features with such elements of dialects that are more natural to man. The language situation in the MDC has been described in the article, its main phonetic, lexical and grammatical properties have been studied. Among the phonetic features have been found the following: merging the vowels of the back row of the lower elevation / $\mathrm{s}$ : / and /p/; use of schwa [ə] (middle row of middle rise in the stressed position); fronting / ov /; fronting / u: /; Fronting of / av /; epenthetic / I $/$; short- $a$ phoneme, $/ æ /$; fronting of $/ \Lambda /$; lowering of /eI/. The grammatical features included "positive" anymore; need, want, or like + past participle; construction like + past participle; "All the + comparative" and Alls at the beginning of a sentence (alls [subject] [verb]) can be used in place of "all that [subject] [verb]" to form a noun At the lexical level, a number of lexical items that are unique to the area have been also identified, which together add a unique color and are a tool for self-identification of the inhabitants of the studied area.

The advanced areas for further scientific development are studying the linguistic variability of dialects of the MDC from the point of view of the sociolinguistic approach of Eco linguistics at the phonetic and lexical linguistic levels in accordance with the influence of extra lingual factors on the speech used there. The relevance of such research will be determined, first, by a new perspective on the analysis of speech variability depending on the influence of selected extra lingual factors: gender, ethnicity, social status and age, which, of course, corresponds to the current state of linguistics and growing interest in the social factors influencing on the speech in different areas, as well as the application of an Eco linguistic approach to the analysis of sociolinguistic differentiation of the MDC. Second, the study will be quite interesting in light of the importance of the sociocultural role of the dialects of the MDC in the holistic linguistic pattern of the United States of America.

\section{BIBLIOGRAPHY}

1. Lakoff R. Language and Women’s Place. Vol. 2 Language in Society. № 1. Cambridge : Cambridge University Press, 1973. P. 45-79.

2. Zimmerman D. H, C. West. Sex roles, interruptions and silences in conversation. Language and Sex: difference and dominance. / edited by B. Thomas and N. Henly. Rowley, MA : Newbury House, 1975. P. 105-129.

3. English only movement: web-site. URL: https://en.wikipedia.org/wiki/English-only_movement\#cite_note-44. (Дата звернення: 30.11.21)

4. English only movement: web-site. URL: https://en.wikipedia.org/wiki/English-only_movement\#cite_noteCrawford50-33. (Дата звернення: 30.11.21)

5. H.R.997 - English Language Unity Act of 2013. URL: https://www.congress.gov/bill/113th-congress/house-bill/997/ text\#H9249221781A3424F85619C1C136AD239. (Дата звернення: 30.11.21)

6. Wisnosky M. 'Pittsburghese' in Pittsburgh humor: Master's thesis in Linguistics / University of Pittsburgh, Pittsburhg, 2003. 103 p. 
7. Languages spoken (at home) other than English in the United States by number of speakers in 2019. URL: https:// www.statista.com/statistics/183483/ranking-of-languages-spoken-at-home-in-the-us-in-2008/. (Дата звернення: 30.11.21)

8. Immigrants in the United States. URL: https://www.americanimmigrationcouncil.org/research/immigrantsin-the-united-states? cf_chl_jschl_tk_=pmd 8c6407cc10ab08643d20d2aaf01740836ab2746b-1626768688-0gqNtZGzNAjijcnBszQjO. ( (Дата звернення: $30.11 . \overline{2} 1$ )

9. US Census Bureau Quick Facts: United States. URL: https://www.census.gov/quickfacts/fact/table/US/PST045219. (Дата звернення: 30.11.21)

10. Yale Grammatical Diversity Project English in North America. URL: https://ygdp.yale.edu/phenomena/needswashed. (Дата звернення: 30.11.21)

11. Chambers J. K. TV Makes People Sound the Same. Language Myths./ edited by L. Bauer, \& P. Trudgill. New York : Penguin Books, 1998. P. 123-32.

12. Kurath H. Western Pennsylvania. A Word Geography of the Eastern United States. Ann Arbor : University of Michigan Press, 1949. $261 \mathrm{p}$.

13. Kurath H., McDavid R. The Pronunciation of English in the Atlantic States. Ann Arbor: University of Michigan Press, 1961. $182 \mathrm{p}$.

14. Eberhardt M. The low back merger in the Steel City: AAE in Pittsburgh. American speech. 2008. № 83. P. 284-311.

15. Eckert P., S. McConnell-Ginet. Language and Gender. Cambridge: Cambridge University Press, 2003. 366 p.

16. Thomas E. Rural Southern white accents. A handbook of Varieties of English: A Multimedia Reference Tool. / edited by B. Kortmann and E. W. Schneider. Berlin, Boston : De Gruyter Mouton, 2008. P. 300-324

17. Labov W. Ash S., B. Charles. The Atlas of North American English. Berlin: Mouton-de Gruyter. 2006. 266 p.

\section{REFERENCES}

1. Lakoff R. Language and Women’s Place. Vol. 2 Language in Society. № 1. Cambridge: Cambridge University Press, 1973. P. 45-79.

2. Zimmerman D. H, C. West. Sex roles, interruptions and silences in conversation. Language and Sex: difference and dominance. / edited by B. Thomas and N. Henly. Rowley, MA: Newbury House, 1975. P. 105-129.

3. English only movement: web-site. URL: https:/en.wikipedia.org/wiki/English-only_movement\#cite_note-44. (Accessed on 30.11.21)

4. English only movement: web-site. URL: https://en.wikipedia.org/wiki/English-only_movement\#cite_noteCrawford50-33. (Accessed on 30.11.21)

5. H.R.997 - English Language Unity Act of 2013. URL: https://www.congress.gov/bill/113th-congress/house-bill/997/ text\#H9249221781A3424F85619C1C136AD239. (Accessed on 30.11.21)

6. Wisnosky M. 'Pittsburghese' in Pittsburgh humor: Master's thesis in Linguistics / University of Pittsburgh, Pittsburhg, 2003. $103 \mathrm{p}$.

7. Languages spoken (at home) other than English in the United States by number of speakers in 2019. URL: https://www.statista.com/statistics/183483/ranking-of-languages-spoken-at-home-in-the-us-in-2008/. (Accessed on 30.11.21)

8. Immigrants in the United States. URL: https://www.americanimmigrationcouncil.org/research/immigrantsin-the-united-states? cf chl_jschl_tk_=pmd_8c6407cc10ab08643d20d2aaf01740836ab2746b-1626768688-0gqNtZGzNAjijcnBszQjO. (Accessed on 30.11.21)

9. US Census Bureau Quick Facts: United States. URL:https://www.census.gov/quickfacts/fact/table/US/PST045219. (Accessed on 30.11.21)

10. Yale Grammatical Diversity Project English in North America. URL: https://ygdp.yale.edu/phenomena/needswashed. (Accessed on 30.11.21)

11. Chambers J. K. TV Makes People Sound the Same. Language Myths./ edited by L. Bauer, \& P. Trudgill. New York: Penguin Books, 1998. P. 123-32.

12. Kurath H. Western Pennsylvania. A Word Geography of the Eastern United States. Ann Arbor: University of Michigan Press, $1949.261 \mathrm{p}$.

13. Kurath H., McDavid R. The Pronunciation of English in the Atlantic States. Ann Arbor: University of Michigan Press, $1961.182 \mathrm{p}$.

14. Eberhardt M. The low back merger in the Steel City: AAE in Pittsburgh. American speech. 2008. № 83.P. 284-311.

15. Eckert P., S. McConnell-Ginet. Language and Gender. Cambridge: Cambridge University Press, 2003. 366 p.

16. Thomas E. Rural Southern white accents. A handbook of Varieties of English: A Multimedia Reference Tool. / edited

by B. Kortmann and E. W. Schneider. Berlin, Boston: De Gruyter Mouton, 2008. P. 300-324

17. Labov W. Ash S., B. Charles. The Atlas of North American English. Berlin: Mouton-de Gruyter. 2006. 266 p. 